\title{
A link between cell movement and gene expression argues that motility is required for cell-cell signaling during fruiting body development
}

\author{
Lee Kroos, ${ }^{1}$ Patricia Hartzell, Karen Stephens, ${ }^{2}$ and Dale Kaiser \\ Department of Biochemistry, Stanford University, Stanford, California 94305 USA
}

\begin{abstract}
Nonmotile mutants of Myxococcus xanthus (Myxobacterales) failed to execute the morphogenetic movements required to shape a fruiting body. In addition, nonmotile mutants produced very few spores when plated for fruiting body development at cell densities appropriate for wild-type cells. At higher initial cell densities, the proportion of nonmotile cells that sporulate increased, indicating that one important function of motility in fruiting body development is to increase the local cell density. However, even at 10 times normal cell density, nonmotile cells sporulated at only $1 \%$ the wild-type level. This sporulation deficiency of nonmotile mutants accompanies an altered pattern of gene expression, monitored by using transcriptional fusions of lac $Z$ to genes expressed at specific times during fruiting body development. Motility was not required for normal expression of five Iac fusions that are expressed within the first $6 \mathrm{hr}$ of fruiting-body development. However, the levels of expression from five lac fusions to later-expressed genes were reduced or abolished in nonmotile strains. $\beta$ -

Galactosidase expression in these late Tn5 lac insertions was increased, and fruiting body development occurred in certain nonmotile strains that can be stimulated to move when mixed with a donor strain. This shows that motility itself is required because the stimulated cells are nonmotile genotypically. The nonmotile mutations had the same effect on developmental $\beta$-galactosidase expression from these 10 lac fusions as an insertion mutation in the csg (formerly spoC) gene. csg mutants have a cell-cell interaction defect that blocks fruiting body development at $\sim 6 \mathrm{hr}$. The similarity in the pattern of developmental expression of motility mutants and csg mutants suggests that motility is required for this csg-mediated cell-cell interaction.
\end{abstract}

[Key Words: Cell-cell interactions; Myxobacterales; transcriptional fusion; gliding; gene regulation]

Received August 2, 1988; revised version accepted October 11, 1988.

Myxococcus xanthus (Myxobacterales) is a Gram-negative soil bacterium that moves by gliding (Reichenbach and Dworkin 1981; Rosenberg 1984). Gliding cells move in the direction of their long axis, and they move only when they are in contact with a surface. When Myxococcus cells are starved at a high cell density on an agar or plastic surface, the process of fruiting body development is induced. The cells glide to aggregation centers and move over each other to construct mounds that have a species-characteristic size and shape. Within a nascent fruiting body, cells differentiate to resting, ovoid spores (Wireman and Dworkin 1975; Inouye et al. 1979; Zusman 1984). In this paper 'development' will be used as shorthand for 'fruiting body development,' and genes whose expression increases at some time during fruiting body development will be referred to as 'developmentally regulated' genes.

Present address: 'Department of Biochemistry, Michigan State University, East Lansing, Michigan 48824 USA; ${ }^{2}$ Department of Human Genetics, Collaborative Research, Inc., 2 Oak Park, Bedford, Massachusetts 01730 USA.
Here, we report that cell motility is required not only to bring cells to an aggregation center but also to activate expression of a particular set of developmentally regulated genes. Many nonmotile mutants of $M$. xanthus have been isolated. Two independent sets of genes have been found to control cell movement, and the motility governed by each set has been characterized. When the gene set called system A (for 'adventurous') is operative, the cells can move on agar whether or not they are near other cells (Hodgkin and Kaiser 1979a). On the other hand, when the set of genes comprising system $S$ (for 'social') alone is operative, cells move only when they are near one another (Hodgkin and Kaiser 1979b). Strains that carry two mutations, one in system $\mathrm{A}$ and one in system $\mathrm{S}$, have an $\mathrm{A}^{-} \mathrm{S}^{-}$genotype and are nonmotile. A second type of nonmotile mutant has been isolated in a single mutational step from wild type. Ten such one-step mutations that map to the same genetic locus, called mgl, have been found (Hodgkin and Kaiser 1979b; Stephens et al., in prep.).

Hagen et al. (1978) isolated four groups of sporulation 
mutants asg, bsg, csg, and $d s g$ (formerly spoA, spoB, $s p o C$, and $s p o D \mid$, which behave as if they are defective in developmentally necessary cell-cell interactions that precede sporulation and upon which sporulation depends. These mutants cannot sporulate alone, but they can be rescued extracellularly for sporulation by codevelopment with wild-type cells or with cells of a different mutant group. These cell-interaction mutants also modify the pattern of developmental gene expression (Kuspa et al. 1986; Kroos and Kaiser 1987). A transposable promoter probe, Tn5 lac (Kroos and Kaiser 1984), has been used to generate transcriptional fusions of $1 a c Z$ to developmentally regulated genes in Myxococcus (Kroos et al. 1986). The assay of $\beta$-galactosidase activity in these fusion strains provides a measure of gene expression during development. It was found that $a s g$ and $b s g$ mutations block or reduce $\beta$-galactosidase expression from lac fusions that normally would begin to be expressed in the first few hours of development in wild-type cells. A csg mutation did not affect expression of lac fusions that are normally expressed in the first 6 hr of development but did block or reduce expression of lac fusions that would normally begin to be expressed after $6 \mathrm{hr}$ of development. Here, we report that nonmotile mutants, both of the one-step mgl type and of the two-step $\mathrm{A}^{-} \mathrm{S}^{-}$type, exhibit the same disruption of developmental gene expression as csg mutants. Although the requirements for asg and bsg cell-cell interactions early in development appear to be met in the absence of motility, the csg interaction appears to require cell movement.

\section{Results}

\section{A nonmotile mutant is defective in fruiting body sporulation}

Normal fruiting body development begins with a phase of aggregation followed by sporulation. To test whether active cell movement is needed for fruiting body development, a one-step mutation to nonmotility, $m g l-9$, was transduced into the fully motile $\left(\mathrm{A}^{+} \mathrm{S}^{+}\right)$and fruitingcompetent genetic background of DK1622, as described in Materials and methods, to construct the nonmotile strain DK3685. The mgl-9 mutant fails to produce mgl protein detectable in Western blots (Stephens el al., unpubl.).

In fact, DK3685 and other mgl-9 strains derived from it do fail to aggregate under the standard conditions of development on plates. Patches of starving DK3685 cells at high density on agar remain flat with no sign of aggregation. Nor do these strains form ripples, the traveling ridges of cells that appear early in normal fruiting-body development (Reichenbach 1965, 1966; Shimkets and Kaiser 1982a).

To test whether an aggregated condition could be simulated in mgl-9 strains by raising the concentration of cells, spore levels were determined for patches of developing $m g l-9$ cells containing a series of increasing densities of cells (Table 1). Under the standard developmental conditions $\left(20 \mu \mathrm{l}\right.$ spots of $5 \times 10^{9}$ cells $/ \mathrm{ml}$ on
Table 1. Sporulation deficiency of an $\mathrm{mgl}^{-}$mutant compared to that of wild type

\begin{tabular}{crc}
\hline \multirow{2}{*}{$\begin{array}{l}\text { Initial density } \\
\text { (cells/ml) }\end{array}$} & \multicolumn{2}{c}{ Sporulation } \\
\cline { 2 - 3 } & spores $/ \mathrm{ml}$ & percent wild type \\
\hline $5 \times 10^{\mathrm{b}}$ & $3 \times 10^{1}$ & 0.002 \\
$1 \times 10^{10}$ & $3 \times 10^{2}$ & 0.02 \\
$2 \times 10^{10}$ & $2 \times 10^{3}$ & 0.1 \\
$3 \times 10^{10}$ & $1 \times 10^{4}$ & 0.5 \\
$4 \times 10^{10}$ & $1.5 \times 10^{4}$ & 0.75 \\
$5 \times 10^{10}$ & $2 \times 10^{4}$ & 1.0 \\
\hline
\end{tabular}

a Strain DK3685 carrying the mgl-9 mutation was grown and inoculated as a concentrated cell suspension at the indicated densities for development and quantitation of spores, as described in Materials and methods.

b The number of spores obtained for the $\mathrm{mgl}^{-}$mutant at the indicated initial density is expressed as a percentage of the number of spores obtained for wild-type strain DK1622 spotted at an initial density of $5 \times 10^{9} \mathrm{cells} / \mathrm{ml}$ in the same experiment.

TPM agar plates), the mgl-9 strain DK3685 formed $0.002 \%$ the number of heat-resistant spores formed by its $\mathrm{mgl}^{+}$parent DK1622 (Table 1). As the initial cell density was raised, by up to 10 -fold, the number of spores increased about 500-fold. Thus, a higher initial cell density may circumvent partially the need for aggregation. But even at the highest cell density tested $(20-\mu)$ spots of $5 \times 10^{10}$ cells $/ \mathrm{ml}$, the mutant produced $2 \times 10^{4}$ spores $/ \mathrm{ml}$, which is only $1 \%$ the number produced by $5 \times 10^{9} / \mathrm{ml}$ of wild-type cells. A $20-\mu \mathrm{l}$ spot of $5 \times 10^{10}$ cells $/ \mathrm{ml}$ forms a layer of cells that is about one-quarter as high as a normal fruiting body (Kuner and Kaiser 1982). The initial cell density was not raised beyond $5 \times 10^{10} / \mathrm{ml}$, as it became very difficult to produce uniform cell suspensions at higher densities.

\section{mgl-9 alters developmental gene expression}

The results of the sporulation with mgl-9 (Table 1) showed that increasing the cell density artificially did not restore sporulation levels seen in wild type. To find an additional cause of reduced sporulation, developmental gene expression was compared in $\mathrm{mgl}^{+}$and mgl-9 strains. Ten different transcriptional fusions between developmentally regulated promoters in Myxococcus and the lacZ gene from Escherichia coli, described by Kroos et al. (1986), were made mgl-9 by transduction. The strains are listed in Table 2. These fusion strains were chosen because each one normally begins its major increase in $\beta$-galactosidase at a different time in development (expression time). The expression times for the 10 fusions chosen cover different parts of the interval from a few minutes after starvation initiates development to the time when spores begin to mature (Table 3). Of the 10 fusions chosen, 8 permitted normal development when present in the $m g l^{+}$background. The exceptions, fusions $\Omega 4408$ and $\Omega 4414$, produce defects that are manifested later in development than their ex- 
Table 2. lac fusion strains

\begin{tabular}{|c|c|c|c|c|c|c|}
\hline \multirow[b]{2}{*}{$\Omega^{\mathbf{a}}$} & \multirow[b]{2}{*}{ Motileb } & \multicolumn{5}{|c|}{ Nonmotile derivatives } \\
\hline & & $m g l-9$ & aglE2 sglB46 & aglBl tgl-1 & $a g l B 1 \operatorname{slg} G 1$ & $\operatorname{cglB2} \operatorname{sglCl}$ \\
\hline 4273 & DK4290 & DK4173 & DK6110 & DK6120 & DK6130 & DK6140 \\
\hline 4401 & DK4293 & DK4170 & DK6111 & DK6121 & DK6131 & DK6141 \\
\hline 4403 & DK4368 & DK4177 & DK6112 & DK6122 & DK6132 & DK6142 \\
\hline 4408 & DK4300 & DK4171 & DK6113 & DK6123 & DK6133 & DK6143 \\
\hline 4414 & DK5279 & DK4172 & DK6114 & DK6124 & DK6134 & DK6144 \\
\hline 4435 & DK5204 & DK4167 & DK6115 & DK6125 & DK6135 & DK6145 \\
\hline 4455 & DK5206 & DK4176 & DK6116 & DK6126 & DK6136 & DK6146 \\
\hline 4469 & DK4469 & DK4168 & DK6117 & DK6127 & DK6137 & DK6147 \\
\hline 4514 & DK4514 & DK4174 & DK6118 & DK6128 & DK6138 & DK6148 \\
\hline 4521 & DK4521 & DK4175 & DK6119 & DK6129 & DK6139 & DK6149 \\
\hline
\end{tabular}

The site of $\operatorname{Tn} 5$ lac insertion is designated by $\Omega$, followed by a number.

b The motile (wild-type) Tn5 lac fusion strains are all in a DK1622 genetic background. Their origin has been described previously (Kroos et al. 1986; Kroos and Kaiser 1987). This table is presented in lieu of a standard strain list.

pression times so they are valid indicators of developmental gene expression (L. Kroos, A. Kuspa, and D. Kaiser, unpubl.|. For measurements of gene expression, each $\mathrm{mgl}^{-}$lac fusion strain was plated for development under the standard conditions; cells were harvested at 6 , $12,18,24,36,48$, and $72 \mathrm{hr}$; and the specific activity of $\beta$-galactosidase was measured in sonic extracts of each sample to obtain a time profile of enzyme activity.

The maximum values of $\beta$-galactosidase activity derived from the time profiles for each lac fusion are summarized in Table 3. Five fusions, listed in the upper part of Table 3, exhibited the same, or higher, maximal specific activities in an mgl-9 strain, as compared with those in an $\mathrm{mgl}^{+}$strain. These are said to give a 'normal' response, neglecting overproduction for the moment. Two fusions, listed in the middle of Table 3 , express $\beta$ galactosidase in the $m g l-9$ background, but at levels that are $25-50 \%$ of those in an $\mathrm{mgl}^{+}$background. These are referred to as 'reduced.' Three fusions listed at the bottom of Table 3, when placed in an mgl-9 background exhibit less than a few percent of the $\beta$-galactosidase activity shown by the corresponding $\mathrm{mgl}^{+}$strain at the time the $\mathrm{mgl}^{+}$strain has reached its maximum $\beta$-galactosidase activity. These fusions are said to have their expression 'abolished' by mgl-9. Examples of the three types of responses are illustrated in the profiles shown in Figure 1: $\Omega 4521$ for a normal response /with overproduction), $\mathbf{\Omega 4 4 1 4}$ for a reduced response, and $\Omega 4435$ for an abolished response.

There is a clear correlation between the time that $\beta$ galactosidase activity begins its major rise (i.e., the 'expression time', as defined by Kroos et al. 1986) in wildtype $\left(\mathrm{mgl}^{+}\right)$strains and the response of the fusion to mgl-9 shown in Table 3. Those lac fusions that are expressed in wild-type cells beginning in the first $5 \mathrm{hr}$ of development give a normal response to $m g l-9$. The two giving a reduced response begin expression later in $\mathrm{mgl}^{+}$ at 9 and $10 \mathrm{hr}$. Finally, the three fusions whose expression is abolished by $\mathrm{mgl}-9$ begin expression in $\mathrm{mgl}^{+}$at $15 \mathrm{hr}$ or later.
Nonmotile mutants of the $A^{-} S^{-}$type alter developmental gene expression

The pattern of developmental gene expression in the $\mathrm{mgl}^{-}$strain was compared with that in four genetically different $\mathrm{A}^{-} \mathrm{S}^{-}$strains to determine whether the pattern correlated with the lack of motility. Figure 2 is a graph of maximum specific $\beta$-galactosidase activity observed from 10 different lac fusions, plotted according to their expression times. Data are presented for $m g l-9$ as wide bars below the midline, and for four different $\mathrm{A}^{-} \mathrm{S}^{-}$ strains as thin bars above the midline, with the same set of lac fusions. Comparing length of bars above and below the midline, a similar pattern of specific enzyme activities is evident in nonmotile mutants of the $\mathrm{A}^{-} \mathrm{S}^{-}$ type and the nonmotile $m g l-9$. In particular, lac fusions normally expressed at $5 \mathrm{hr}$ or before are expressed normally and have a relative specific $\beta$-galactosidase activity of about 1 , except for the fusion $\Omega 4521$ expressed at $1.5 \mathrm{hr}$, which is overexpressed in both $\mathrm{mgl}-9$ and three of the four $\mathrm{A}^{-} \mathrm{S}^{-}$strains. lac fusions whose expression times are 9 and $10 \mathrm{hr}$ are reduced similarly in all four $\mathrm{A}^{-} \mathrm{S}^{-}$and $\mathrm{mgl}-9$ strains; fusions normally expressed at 15,25 , and $30 \mathrm{hr}$ show little, if any, $\beta$-galactosidase activity in mgl-9 or any of the $\mathrm{A}^{-} \mathrm{S}^{-}$nonmotile mutants.

A second kind of experiment that demonstrates the correlation between motility and developmental gene expression utilizes motility stimulation. Cells of genotype $\mathrm{cgl}^{-} \mathrm{tgl}^{-}$are nonmotile $\left(\mathrm{A}^{-} \mathrm{S}^{-}\right)$, yet can have their motility temporarily restored by contact with $\mathrm{cgl}^{+} \mathrm{tgl} \mathrm{I}^{+}$ cells (Hodgkin and Kaiser 1977, 1979a,b). Stimulation is locus specific; and nonmotile cells, as long as they are $\mathrm{cgl}^{+} \mathrm{tgl}^{+}$, can stimulate $\mathrm{cgl}^{-} \mathrm{tgl}^{-}$strains (Hodgkin and Kaiser 1977). For the experiment, stimulatable cells of the genotype cgl tgl Tn5 lac $\Omega 4435$ or $\Omega 4401$ were employed. The fusions $\Omega 4435$ and $\Omega 4401$ are normally expressed at 25 and $30 \mathrm{hr}$ in development, and their expression was abolished in $m g l-9$ or $\mathrm{A}^{-} \mathrm{S}^{-}$strains. These cells are nonmotile, as demonstrated by their sharpedged colonies (Fig. 3a). When they are placed under conditions that induce development, they fail to form 
Table 3. $\beta$-Galactosidase expression in $\mathrm{mgl}^{+}$and $\mathrm{mgl}-9$ strains

\begin{tabular}{|c|c|c|c|c|c|}
\hline \multirow[b]{2}{*}{$\Omega^{\mathrm{a}}$} & \multirow{2}{*}{$\begin{array}{l}\text { Expression } \\
\text { time in } \\
\mathrm{mgl}^{+} \\
(\mathrm{hr})\end{array}$} & \multicolumn{3}{|c|}{$\begin{array}{c}\text { Specific } \\
\beta \text {-galactosidase activity }\end{array}$} & \multirow{2}{*}{$\begin{array}{l}\text { Response } \\
\text { to } \\
m g l-9\end{array}$} \\
\hline & & $\begin{array}{l}\text { in } m g 1^{+} \\
\text {at } \max ^{d}\end{array}$ & $\begin{array}{l}\text { in } m g 1-9 \\
\text { at } t \text { max }^{d}\end{array}$ & $\begin{array}{l}\text { in } m g l-9 \\
\text { at } \max ^{d}\end{array}$ & \\
\hline 4408 & 1 & 38 & 23 & 39 & normal \\
\hline 4521 & 1.5 & 140 & 440 & 460 & normal \\
\hline 4455 & 3 & 470 & 470 & 570 & normal \\
\hline 4469 & 5 & 430 & 320 & 470 & normal \\
\hline 4273 & 5 & 63 & 38 & 110 & normal \\
\hline 4514 & 9 & 280 & 150 & 150 & reduced \\
\hline 4414 & 10 & 1100 & 320 & 420 & reduced \\
\hline 4403 & 15 & 190 & 8 & 25 & abolished \\
\hline 4435 & 25 & $450^{f}$ & 18 & 18 & abolished \\
\hline 4401 & 30 & $220^{f}$ & 2 & 2 & abolished \\
\hline
\end{tabular}

a The site of $\operatorname{Tn} 5$ lac insertion is designated by $\Omega$, followed by a number. Strain numbers are given in Table 2 .

${ }^{b}$ An estimate of when $\beta$-galactosidase specific activity begins its major increase during development (Kroos et al. 1986).

c Values are the specific activity of $\beta$-galactosidase at the specified time minus the specific activity in $t=0$ samples (i.e., cells sedimented from growth medium and resuspended in starvation buffer). The units of $\beta$-galactosidase specific activity are $\mathrm{nmoles} \mathrm{ONP} / \mathrm{min} / \mathrm{mg} /$ protein. Typical values for $t=0$ samples can be found in Kroos and Kaiser (1987).

d Values are the highest $\beta$-galactosidase specific activities measured during a 72 -hr developmental time course for $\mathrm{mgI}^{+}$ (column 3), for $m g l-9$ (column 4) at the time ( $t$ max) when $m g I^{+}$ reaches its peak, and for $m g l-9$ (column 5 ) at its own peak.

e The effect of $m g l-9$ on developmental $\beta$-galactosidase expression from each lac fusion is summarized. Normal indicates $\beta$ galactosidase expression began at the same time and reached the same or higher specific activity in the mgl-9 lac fusion strain than in the wild-type lac fusion strain. Reduced indicates that $\beta$-galactosidase expression began at the same time but increased less rapidly and reached a lower maximum in the $m g l-9$ mutant than in wild type (see text for the quantitative limits). Abolished indicates that no developmental expression occurred in the mgl-9 mutant.

f The maximum $\beta$-galactosidase specific activity was observed when the $72-\mathrm{hr}$ sample was sonicated with glass beads to disrupt spores (Kroos et al. 1986). Sonication with glass beads did not change the $\beta$-galactosidase specific activities of $72-\mathrm{hr}$ samples of $\mathrm{mgl}^{-}$lac fusion strains, as expected, because these samples contain very few spores.

fruiting bodies (Fig. 3c), and they express a low level of $\beta$-galactosidase, $<10 \%$ of the maximum level measured for developing wild-type cells (Table 4). For stimulation, these cells were mixed with mgl-9 cells (DK4141), also nonmotile, and nonstimulatable (Hodgkin and Kaiser 1979b). The cgl tgl cells are able to move in this mixture (Fig. 3b); a fringe of cells have moved away from the edge of the original drop, revealing that cells have been stimulated. The same cell mixture was placed on a starvation medium to induce development. Aggregates formed on these plates (Fig. $3 \mathrm{~d}$ ) and $\beta$-galactosidase were expressed at a higher level than the nonstimulated control (Table 4). When the mgl-9 (DK4141) cells were replaced by wild-type cells (DK1622), $\beta$-galactosidase from the recipient rose even higher, probably reflecting more efficient stimulation by a motile donor than by one that is nonmotile.

An additional control experiment was performed because the fusions $\Omega 4401$ and $\Omega 4435$, employed in the stimulation experiment, depend on a cell-to-cell signal, $\mathrm{C}$-signal, for $\beta$-galactosidase expression (Kroos and Kaiser 1987). To test the possibility that the increased $\beta$-galactosidase production in cell mixtures might be due to provision of an excess of C-signal, rather than to motility stimulation, a donor strain was employed that is deficient in C-signal production. Data in the last column of Table 4 show that when strain DK2634, which is csgand, hence, deficient in C-signal production (Kroos and Kaiser 1987), was the donor, $\beta$-galactosidase was still efficiently produced from all four recipient strains.

\section{Discussion}

mgl mutant cells fail to aggregate, and they produce very few spores when plated for development at cell densities adequate for fruiting body development of wild-type cells. At higher initial cell densities the proportion of mgl-9 cells that sporulate increases (Table 1), indicating that one important function of motility in Myxococcus development is to increase the local cell density, perhaps to establish cell-cell contacts during the aggregation phase of early development. However, even at the highest cell density tested, mgl-9 cells sporulate at only $1 \%$ the level seen for wild-type cells at a 10 -fold lower density. The mgl-9 mutation also reduces or abolishes the expression of several developmentally regulated genes that are normally expressed after $9 \mathrm{hr}$, during the postaggregation phase of development. Genes expressed early in development are unaffected by $m g l-9$.

The finding that $m g l-9$ prevented the expression of certain developmentally regulated lac fusions raised a question of whether $\mathrm{mgl}$ might encode a regulatory protein that happens to control both gliding and developmental gene expression. This possibility was examined by testing the effect of other mutations that block gliding. Four nonmotile mutants, which carry different pairs of mutations in the A and S motility systems, were tested. The four $\mathrm{A}^{-} \mathrm{S}^{-}$strains revealed an altered pattern of $\beta$-galactosidase expression from lac fusions that was parallel to that of $m g l-9$. In addition, an experiment employing motility stimulation (Hodgkin and Kaiser 1977) showed that expression of the lac fusions $\Omega 4401$ and $\Omega 4435$ can occur if the cells are stimulated to move, even when they are genotypically nonmotile. Stimulation also allowed fruiting body aggregates to form, indicating that other developmental functions needed for aggregation that are motility dependent can also occur following stimulation. The requirement for motility during fruiting body development is first manifest between 5 and $9 \mathrm{hr}$ after starvation: All five lac fusions that normally begin $\beta$-galactosidase expression at or before $5 \mathrm{hr}$ of development were expressed normally in the nonmotile $m g l-9$ or $\mathrm{A}^{-} \mathrm{S}^{-}$mutants, whereas all five lac fusions 

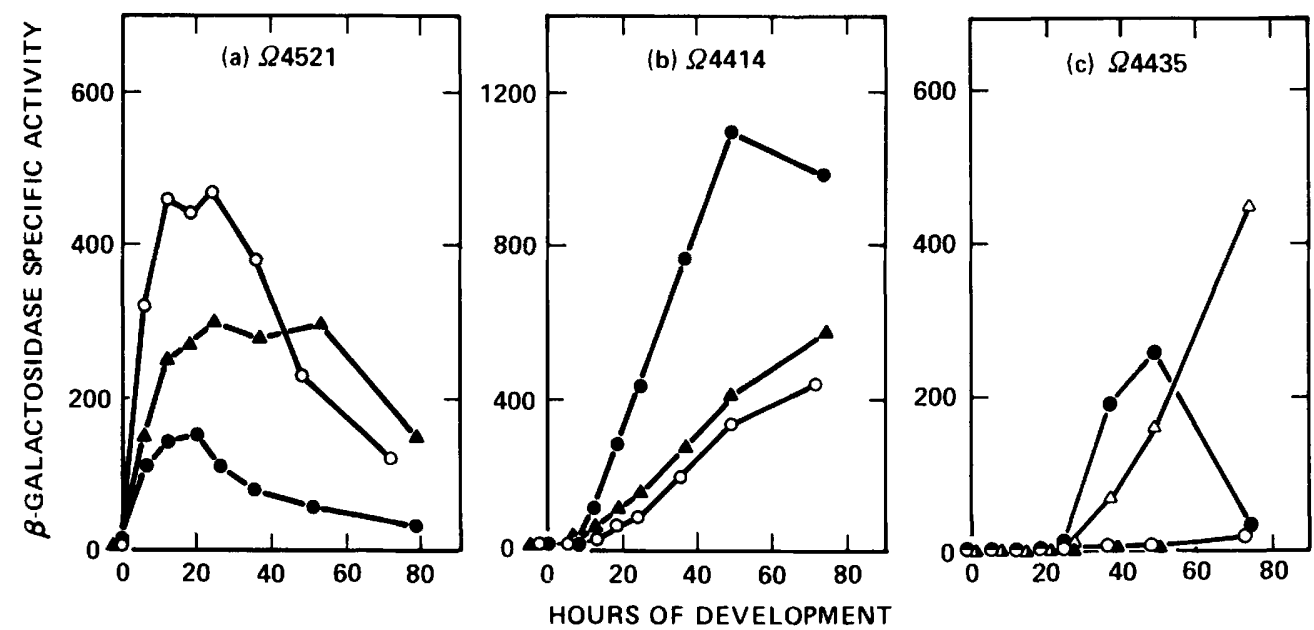

Figure 1. Kinetics of developmental gene expression, comparing the effects of $m g I-9$ and $c s g$ mutations on gene expression. Wild-type $(\bullet), m g l-9$ (O), and csg :: $\Omega 205$ ( $\Delta$ ) strains containing Tn5 lac insertion $\Omega 4521(a), \Omega 4414(b)$, or $\Omega 4435(c)$ were plated for development and harvested at various times for determination of $\beta$-galactosidase specific activity (nmole ONP/min $\cdot \mathrm{mg}$ of protein), as described in Materials and methods. The $\triangle$ in $c$ indicated the $\beta$-galactosidase specific activity released from wild-type samples sonicated with glass beads, a procedure that breaks open spores (Teintze et al. 1985).

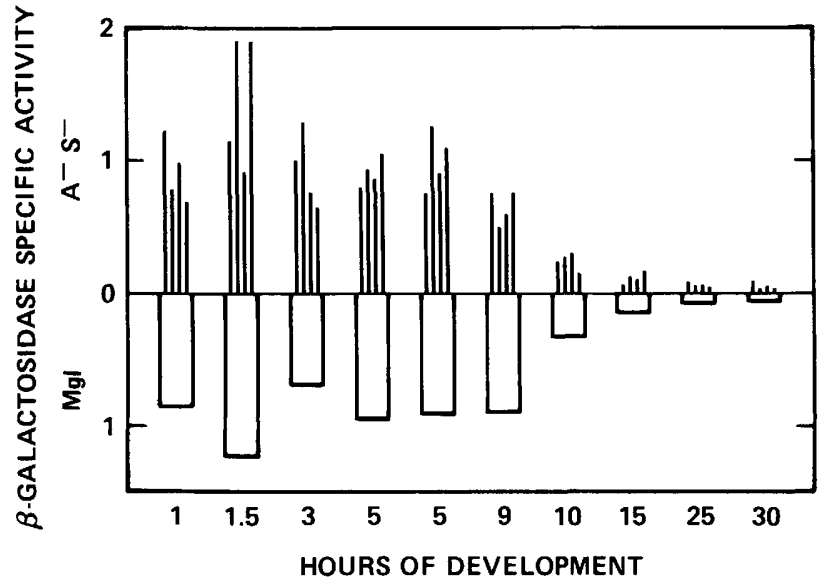

Figure 2. Maximum specific $\beta$-galactosidase activity reached from each of 10 developmentally regulated lac fusions, each one in five different nonmotile strains. Data for each lac fusion are clustered according to $\beta$-galactosidase expression time in wild-type for each fusion, shown on the $x$ axis. Note that the time scale is not linear. Thus, the data at $1 \mathrm{hr}$ are all for fusion $\Omega 4408$, at $1.5 \mathrm{hr}$ for $\Omega 4521$, at $3 \mathrm{hr}$ for $\Omega 4455$, at $5 \mathrm{hr}$ for $\Omega 4469$, at $5 \mathrm{hr}$ (second one) for $\Omega 4273$, at $9 \mathrm{hr}$ for $\Omega 4514$, at $10 \mathrm{hr}$ for $\Omega 4414$, at $15 \mathrm{hr}$ for $\Omega 4403$, at $25 \mathrm{hr}$ for $\Omega 4435$, and at $30 \mathrm{hr}$ for $\Omega 4401$. Four different $\mathrm{A}^{-} \mathrm{S}^{-}$genotypes are shown above the horizontal midline. The length of each vertical line represents the maximum specific $\beta$-galactosidase activity in the nonmotile $\left(\mathrm{A}^{-} \mathrm{S}^{-}\right)$strain relative to that in the wild-type $\left(\mathrm{A}^{+} \mathrm{S}^{+}\right.$, $\mathrm{DK} 1622)$. The $\mathrm{A}^{-} \mathrm{S}^{-}$combinations are shown in the same order for each cluster; the order reading left to right is agIE2 sglB46, aglB1 tgl-1, aglB1 sglGl, and $c g l B 2$ sglCl. Maximum specific activity for the mgl-9 nonmotile is shown by the length of the wide bar extending below the midline. Data for $m g l-9$ were obtained in the same experiment, and their specific activity is expressed relative to the same fusions in DK1622. that normally begin expression after $9 \mathrm{hr}$ of development, like $\Omega 4401$ and $\Omega 4435$, had reduced expression or failed to be expressed.

\section{$\beta$-Galactosidase expression pattern in nonmotile mutants parallels that in csg cell interaction mutants}

Nonmotile cells exhibit a specific disruption of gene expression evident in developmentally regulated lac fusion strains. Kuspa et al. (1986) and Kroos and Kaiser (1987) have examined the effect of three classes of cell-interaction mutants asg, bsg, and csg on the same set of lac fusions. Comparison of these data reveals a parallel between the consequences of loss of motility and the consequences of a null mutation in the cell-interaction locus csg. The $\beta$-galactosidase data for mutations in two different asg genes, for an insertion mutation in a bsg gene, and for an insertion in the csg gene are summarized in Table 5, where they can be compared with the corresponding pattern for $\mathrm{mgl}$ or $\mathrm{A}^{-} \mathrm{S}^{-}$nonmotile mutants. Table 5 indicates whether the expression of $\beta$-galactosidase during development for each of the 10 lac fusions is normal, i.e., approximately the same or higher than wild type; reduced, i.e., between $15 \%$ and $65 \%$ that of wild type; or abolished, i.e., $<15 \%$ that of wild-type.

No similarity is evident between the nonmotile mutants and asg or bsg mutants, as shown in Table 5. However, the pattern for the nonmotile mutants and for csg is the same. The parallel between nonmotile mutants and csg mutants not only includes the identity of lac fusions that are expressed but also the kinetics of $\beta$-galactosidase-specific activity in individual lac fusion 


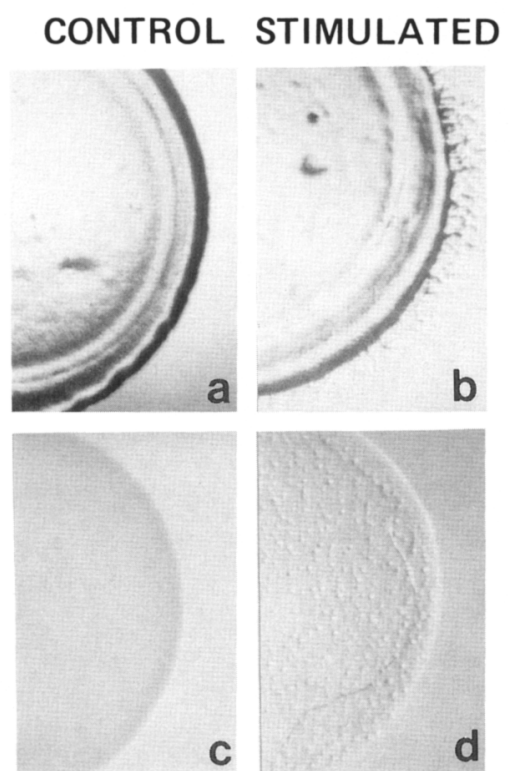

Figure 3. Stimulation of motility and aggregation. $(a)$ The edge of a spot of $\mathrm{cgl}^{-} \mathrm{tgl}-$ cells on CTT agar. The sharp edge shows the absence of motility. (b) Edge of mixed spot of $\mathrm{cgl}^{-} \mathrm{tgl} \mathrm{I}^{-}$cells and mgl-9 on CTT agar. The fringe extending beyond the original spot toward the right shows stimulation of motility. (c) Sector of a spot of $\mathrm{cgl} \mathrm{tgl}^{-}$cells on TPM agar after $40 \mathrm{hr}$ at $32^{\circ} \mathrm{C}$. (d) Sector of a mixed spot of $\mathrm{cgl} \mathrm{I}^{-} \mathrm{tgl^{- }}$ and $\mathrm{mgl}-9$ cells on TPM agar after $40 \mathrm{hr}$ at $32^{\circ} \mathrm{C}$. Aggregates are evident within the spot.

strains. For example, in one set of experiments, higher than normal maximal $\beta$-galactosidase specific activities were observed of $m g l-9$ lac fusion strains containing $\Omega 4455, \Omega 4469$, and $\Omega 4273$ (Table 3); higher than normal levels were also observed for csg strains containing these same lac fusions (Kroos and Kaiser). For these particular fusion strains, $\beta$-galactosidase activity in the $m g l-9$ and csg derivatives paralleled the activity in the wild-type strain until it reached a peak, but it continued to increase in the mutants at a point where activity had fallen in the wild-type strain. For the fusion $\Omega 4521$, $\beta$ - galactosidase expression reached a higher peak in the csg derivative than in the wild-type strain at the time of the wild-type peak, and expression from $\Omega 4521$ reached an even higher peak in the mgl-9 derivative (Fig. 1a). Both the $m g l-9$ and the csg mutations reduced expression from lac fusion $\Omega 4414$ to similar extents (Fig. lb). Finally, the level of expression of $\Omega 4435$ is abolished in the same way by $c s g$ and $m g l-9$ (Fig. 1c).

Kroos and Kaiser (1987) showed that $\mathrm{asg}^{+}$and $\mathrm{bsg}^{+}$ functions precede $\mathrm{csg}^{+}$function on the same regulatory pathway. csg mutants behave as though they are unable to produce a cell interaction necessary to continue development and associated gene expression beyond $6 \mathrm{hr}$ (Kroos and Kaiser 1987). Cell movement might be required for the csg-mediated cell interaction to generate, transfer, or receive a 'C-signal.'

It appears that at the high initial cell densities employed standardly in our experiments to study development, motility is not essential until about the same time that the $\operatorname{csg}^{+}$-dependent cell-cell interaction is required. In contrast, the $a s g^{+}$- and $b s g^{+}$-dependent cellcell interactions must occur in the absence of movement, as two lac fusions ( $\Omega 4521$ and $\Omega 4273$ ) that are partially bsg ${ }^{+}$-dependent (Kroos and Kaiser 1987) and absolutely asg $^{+}$-dependent (Kuspa et al. 1986) are expressed normally or are overexpressed in the nonmotile strains (Table 3 and 5).

The suggested link between motility and $\mathrm{C}$ signaling may help to explain why csg mutants fail to form ripples (Shimkets and Kaiser 1982). Ripples are ridge-shaped accumulations of cells that move in the synchronous, pulsating manner of traveling waves and are usually generated early in fruiting-body development (Reichenbach 1965, 1966; Shimkets and Kaiser 1982). If C-signaling caused cells to move, then a positive feedback loop would be created (movement, C-signaling, movement, etc.), which could result in an oscillation that would produce rippling. The feedback loop would be broken, either by loss of motility or a mutation in csg, and both have been observed to be needed for rippling (Shimkets and Kaiser 1982; Shimkets et al. 1983).

Table 4. Motility stimulation increases development-specific $\beta$-Galactosidase activity

\begin{tabular}{|c|c|c|c|c|c|c|}
\hline \multirow[b]{2}{*}{ Strain } & \multirow[b]{2}{*}{$\begin{array}{l}\text { Motility } \\
\text { genotype }\end{array}$} & \multirow[b]{2}{*}{$\begin{array}{l}\text { Tn5 lac } \\
\text { insertion }\end{array}$} & \multicolumn{4}{|c|}{$\beta$-Galactosidase specific activity ${ }^{a}$} \\
\hline & & & unstimulated & $\begin{array}{l}\text { stimulated by } \\
\text { a nonmotile } \\
\text { strain } \\
\text { (Dk4141) }\end{array}$ & $\begin{array}{l}\text { stimulated by } \\
\text { a wild-type } \\
\text { strain } \\
\text { (DK1622) }\end{array}$ & $\begin{array}{l}\text { stimulated by } \\
\text { a csg- } \\
\text { strain } \\
\text { (DK2634) }\end{array}$ \\
\hline DK6155 & $\operatorname{cglF} 1 \operatorname{tgl}-3$ & $\Omega 4435$ & 43 & 110 & 245 & 219 \\
\hline DK6165 & $\operatorname{cglE} 4 \operatorname{tgl}-1$ & $\mathbf{\Omega} 4435$ & 27 & 81 & 163 & 147 \\
\hline DK6151 & $\operatorname{cglF} 1 \operatorname{tgl}-3$ & $\Omega 4401$ & 23 & 78 & 145 & 129 \\
\hline DK6161 & cglE4 tgl-1 & $\Omega 4401$ & 15 & 47 & 96 & 105 \\
\hline
\end{tabular}

Experimental protocol is given in Materials and methods.

a Specific activity in nmoles $\mathrm{ONP} / \mathrm{min} / \mathrm{mg} /$ protein. Values listed are for the maximum $\beta$-galactosidase activities measured during the 72-hr developmental time course. To disrupt spores, glass beads were added to the harvested cells, as described in footnote $f$ to Table 3 . 
Table 5. Expression patterns in cell-interaction and nonmotile mutants

\begin{tabular}{lllllll}
\hline & $\begin{array}{l}\text { Expression } \\
\text { time }\end{array}$ & \multicolumn{5}{c}{$\beta$-Galactosidase profile } \\
\cline { 3 - 7 }$(\mathrm{hr})$ & $\mathrm{asg}$ & bsg & csg & $m g l-9$ & $\mathrm{~A}^{-} \mathrm{S}^{-}$ \\
\hline 4408 & 1 & $\mathrm{n}$ & $\mathrm{r}$ & $\mathrm{n}$ & $\mathrm{n}$ & $\mathrm{n}$ \\
4521 & 1.5 & $\mathrm{a}$ & $\mathrm{r}$ & $\mathrm{n}$ & $\mathrm{n}$ & $\mathrm{n}$ \\
4455 & 3 & $\mathrm{n}$ & $\mathrm{r}$ & $\mathrm{n}$ & $\mathrm{n}$ & $\mathrm{n}$ \\
4469 & 5 & $\mathrm{n}$ & $\mathrm{r}$ & $\mathrm{n}$ & $\mathrm{n}$ & $\mathrm{n}$ \\
4273 & 5 & $\mathrm{a}$ & $\mathrm{r}$ & $\mathrm{n}$ & $\mathrm{n}$ & $\mathrm{n}$ \\
4514 & 9 & $\mathrm{a}$ & $\mathrm{r}$ & $\mathrm{r}$ & $\mathrm{r}$ & $\mathrm{r}$ \\
4414 & 10 & $\mathrm{a}$ & $\mathrm{a}$ & $\mathrm{r}$ & $\mathrm{r}$ & $\mathrm{r}$ \\
4403 & 15 & $\mathrm{a}$ & & $\mathrm{a}$ & $\mathrm{a}$ & $\mathrm{a}$ \\
4435 & 25 & $\mathrm{a}$ & & $\mathrm{a}$ & $\mathrm{a}$ & $\mathrm{a}$ \\
4401 & 30 & & $\mathrm{a}$ & $\mathrm{a}$ & $\mathrm{a}$ & $\mathrm{a}$ \\
$\mathrm{a}$ & & & & & & \\
\hline
\end{tabular}

The responses of asg, bsg, and csg mutants are taken from Kuspa et al. (1986) and Kroos and Kaiser (1987). The responses for $m g l-9$ are from Table 3; responses for $\mathrm{A}^{-} \mathrm{S}^{-}$are from Fig. 2. a (n) Normal; (r) reduced; (a) abolished.

\section{Materials and methods}

\section{Counting spores during fruiting body development}

Cells growing exponentially in CTT liquid medium (Hodgkin and Kaiser 1977) were sedimented at $10,000 \mathrm{~g}$ for $10 \mathrm{~min}$ at $5^{\circ} \mathrm{C}$ and suspended in TPM buffer [10 mM Tris- $\mathrm{HCl}(\mathrm{pH} 7.5), 1 \mathrm{mM}$ $\left.\mathrm{K}_{2} \mathrm{HPO}_{4} \cdot \mathrm{KH}_{2} \mathrm{PO}_{4}, 8 \mathrm{~mm} \mathrm{MgSO}_{4}\right]$ at densities ranging from $5 \times 10^{9}$ to $5 \times 10^{10}$ cells $\mathrm{ml}$, and $20 \mu \mathrm{l}$ aliquots were spotted on TPM agar (TPM plus $1.5 \%$ agar) in the wells of a 24-well tissueculture plate (Falcon, Lincoln Park, New Jersey). The number of sonication- and heat-resistant viable spores after 3 days of development at $32^{\circ} \mathrm{C}$ was determined. Samples were incubated for $2 \mathrm{hr}$ at $50^{\circ} \mathrm{C}$ and then harvested by adding $0.5 \mathrm{ml}$ of TPM buffer to the well, dislodging the cell mat with a bent loop, and sonicating the suspension for $45 \mathrm{sec}$. Heating resulted in a $10^{7}$-fold loss in viability of vegetative cells and no loss of viability of myxospores, and the sonication in a 10 -fold loss in viability of vegetative cells and no loss in viability of myxospores (Hagen et al. 1978). Appropriate dilutions of the spore-containing samples were made in TPM buffer and mixed with $2.5 \mathrm{ml}$ of CTT soft agar $(0.7 \%)$ for plating on CTT agar $(1.5 \%)$ plates. Plates were incubated for 6 days at $32^{\circ} \mathrm{C}$ to allow spores to germinate and form colonies, which were then counted.

\section{Construction of $\mathrm{mgl}-\mathrm{Tn} 5$ lac derivatives}

The mgl-9 mutations, used to construct nonmotile Tn5 lac derivative, is linked genetically to Tn5 insertion $\Omega 1901$ (Sodergren and Kaiser 1983; Stephens and Kaiser 1987). The kanamycin resistance $\left(\mathrm{Km}^{\mathrm{r}}\right)$ marker gene of $\operatorname{Tn} 5 \Omega 1901$ was replaced with a tetracycline resistance $\left(\mathrm{Tc}^{\mathrm{r}}\right)$ marker gene (Avery and Kaiser 1983 ) so that the mgl-9 mutation could be introduced into $\mathrm{Km}^{\mathrm{r}}$ Tn5 lac strains by generalized transduction and selection for $\mathrm{Tc}^{\mathrm{r}}$. In practice, $M$. xanthus strain DK3685 containing mgl-9 and $\mathrm{Tc}^{\mathrm{r}}$ at $\Omega 1901$ was constructed as described below and was used as the donor in myxophage $\mathrm{Mx} 8$ transductions. A liquid phage stock of $\mathrm{Mx} 8 \mathrm{clp} 2$ was grown on DK3685, as described previously (Kroos and Kaiser 1987), and was used to transduce Tn5 lac insertion-containing strains that have been described (Kroos et al. 1986) to $\mathrm{Tc}^{\mathrm{r}}$, also described (Avery and Kaiser
1983). The $\mathrm{Tc}^{\mathrm{r}}$ of transductants was scored by transfer to CTT agar plates containing $12.5 \mu \mathrm{g} / \mathrm{ml}$ oxytetracycline. Nonmotile $\mathrm{Tc}^{\mathrm{r}}$ transductants arose at the expected frequency $180-85 \%$ of $\mathrm{Tc}^{\mathrm{r}}$ colonies), based on previous studies of genetic linkage between $\Omega 1901$ and $\mathrm{mgl}^{-}$mutations (Sodergren and Kaiser 1983; Stephens and Kaiser 1987). For each strain constructed, 10-15 nonmotile, $\mathrm{Tc}^{\mathrm{r}}$ transductants were transferred to CTT agar plates containing $40 \mu \mathrm{g} / \mathrm{ml}$ kanamycin sulfate to test for retention of the Tn5 lac insertion. All nonmotile $\mathrm{Tc}^{\mathrm{r}}$ transductants were also $\mathrm{Km}^{\mathrm{r}}$ for all strains constructed, indicating an absence of genetic linkage (i.e., $<7-10 \%$ cotransduction) between any of the Tn5 lac insertions listed in Table 2 and $\mathrm{Tc}^{\mathrm{r}}$ at $\Omega 1901$ among nonmotile transductants. The nonmotile, $\mathrm{Tc}^{r}, \mathrm{Km}^{r}$ transductants were screened for $\beta$-galactosidase activity during growth and development on plates containing 5-bromo-4chloro-3-indolyl- $\beta$-D-galactoside (X-Gal), as described previously (Kroos et al. 1986). For each cross, one transductant that displayed colony color (on the X-Gal plates) typical of the majority of transductants for the cross was chosen for further study and given a strain number (see Table 2). As described previously (Kuspa et al. 1986), in such crosses, transductants with aberrant $\beta$-galactosidase expression arise at a low frequency $(0.2 \%)$ and the colony color screen avoids their isolation.

The $M$. xanthus donor strain DK3685 containing mgl-9 and $\operatorname{Tn} 5 \mathrm{Tc}^{\mathrm{r}}$ at $\Omega 1901$ was constructed as follows: DK371 (Hodgkin and Kaiser 1979al, which carries the mgl-9 mutation, was the recipient of an Mx8 transduction (Avery and Kaiser 1983) in which DK1901 carrying Tn5 21901 was the donor; a nonmotile $\mathrm{Km}^{\mathrm{r}}$ transductant was chosen and was the donor of an $\mathrm{Mx} 8$ transduction with the wild-type strain DK1622 as the recipient; a nonmotile $\mathrm{Km}^{\mathrm{r}}$ transductant was chosen and was infected with P1 :: Tn5-132 (bacteriophage P1 bearing a $\mathrm{Tc}^{\mathrm{r}}$ version of Tn5), as described by Avery and Kaiser (1983), to obtain $\operatorname{Tc}^{\mathrm{r}}$ at position $\Omega 1901$. The resulting nonmotile, $\mathrm{Tc}^{\mathrm{r}} \mathrm{Km}^{\mathrm{s}}$ strain, DK3685, has $\mathrm{Tc}^{\mathrm{r}}$ at the $\Omega 1901$ site, as verified by Southern blot hybridization analysis (data not shown), and was used to transduce the mgl-9 mutation into lac fusion strains, as described above.

\section{Construction of $A^{-} S^{-}$Tn5 lac derivatives}

The generalized transducing myxophage $M x 4$ ts 18 ts 27 (Campos et al. 1978) was used to introduce Tn5 lac insertions into four different $\mathrm{A}^{-} \mathrm{S}^{-}$strains. As the transducing capacity of $\mathrm{Mx} 4$ is $\sim 50 \mathrm{~kb}$ of DNA, Tn 5 lac from the donor is transferred to the recipient by homologous recombination, because recombination is more frequent than transposition, thus preserving the original site of $\operatorname{Tn} 5$ lac insertion and its corresponding regulation (Kroos et al. 1986). Plate stocks of Mx4 grown on the 10 donor strains carrying Tn5 lac $\Omega 4273$, $\Omega 4401, \Omega 4403, \Omega 4408$, $\Omega 4414, \Omega 4435, \Omega 4455, \Omega 4469, \Omega 4514$, and $\Omega 4521$ (Kroos et al. 1986) were used to transduce $A^{-} S^{-}$recipients to $\mathrm{Km}^{\mathrm{r}}$, as described elsewhere (Avery and Kaiser 1983). The $\mathrm{A}^{-\mathrm{S}^{-}}$strains used were DK1246 (aglE2, sglB46), DK1250 |aglB1, tgl-1), DK1259 (aglB1, sglG1), and DK1261 (cglB2, sglC1), described previously (Hodgkin and Kaiser 1979b). Nonmotile, $\mathrm{Km}^{\mathrm{r}}$ transductants were selected and used in the subsequent developmental $\beta$-galactosidase assays, as described below. For consistency, the set of nonmotile strains having the same $\operatorname{Tn} 5$ lac insertion was assayed as a group. For example, wild-type, mgl-9 and each of the four $\mathrm{A}^{-} \mathrm{S}^{-}$strains carrying the insertion $\Omega 4414$ were all assayed at the same time, starting with the spotting of cultures on TPM agar plates through the $\beta$-galactosidase and protein assays, described below. 


\section{Measurement of developmental $\beta$-galactosidase expression}

Expression of $\beta$-galactosidase from $\mathrm{Tn} 5$ lac insertion-containing $M$. xanthus strains was quantitated, as described previously (Kroos et al. 1986). Cells growing exponentially in CTT liquid medium were sedimented and resuspended in TPM buffer to a density of $5 \times 10^{9} \mathrm{cells} / \mathrm{ml}$. A $0.1-\mathrm{ml}$ aliquot was added to $0.3 \mathrm{ml}$ of TPM and was stored at $-20^{\circ} \mathrm{C}$ for later determination of $\beta$-galactosidase activity in growing (vegetative) cells. This aliquot was the $t=0$-hr sample. For development, $20-\mu \mathrm{l}$ aliquots were spotted on TPM agar plates, the spots were allowed to dry for $1 \mathrm{hr}$ at room temperature, and plates were incubated at $32^{\circ} \mathrm{C}$. At various times, cells were scraped from the agar into TPM buffer and stored at $-20^{\circ} \mathrm{C}$ until all samples were collected. The specific activity of $\beta$-galactosidase [1 unit $=1$ nmole $o$-nitrophenol (ONP) produced per minute per milligram protein] in each sample was determined after sonication to disrupt the cells.

\section{Stimulation}

The two Myxococcus strains, DK1252 (cglF1, tgl3) and DK1255 (cglE4, tgl1), carry mutations in both motility systems (Hodgkin and Kaiser 1979b), which render these strains stimulatable. Into these two genetic backgrounds, Tn5 lac insertions $\Omega 4401$ and $\Omega 4435$ were introduced by $M x 4$ transduction to generate the four different stimulatable $\mathrm{A}^{-} \mathrm{S}^{-}$strains in Table 4. These can be stimulated to move transiently by a donor strain of $M$. xanthus, which is $\mathrm{cgl}^{+}, \mathrm{tgl}^{+}$(Hodgkin and Kaiser 1979b). The donor strains tested were DK4141 ( $\mathrm{mgl}-9$, which is nonmotile itself, but $\mathrm{cgl}^{+} \mathrm{tgl}^{+}$), DK1622 (wild type), and DK2634 $\left(\mathrm{csg}^{-}\right.$, a fully motile strain that is defective as a donor for Csignal). None of the three donor strains have Tn5 lac, and they produce no $\beta$-galactosidase themselves.

For a stimulation experiment, recipient strains were grown at $33^{\circ} \mathrm{C}$ in $10 \mathrm{ml}$ of CTT liquid plus kanamycin monosulfate 140 $\mu \mathrm{g} / \mathrm{ml}$, Sigma) to a density of $100-200 \mathrm{Klett} \mathrm{U} / \mathrm{ml}$. Cells were sedimented at $12,000 \mathrm{~g}$ for $10 \mathrm{~min}$ and resuspended in a volume of TPM, which would yield a density of $1000 \mathrm{Klett} \mathrm{U} / \mathrm{ml}$. Donor strains were treated identically, except that the original culture medium did not contain kanamycin. Cells /recipient strain plus donor strain) were mixed in a $1: 1$ ratio prior to spotting the mixture on a TPM plate for development. The protocol for induction of development was identical to that described in the preceding section. Mixtures were spotted in 20and $40-\mu \mathrm{l}$ aliquots to control for the presence of the donor cells (because the normal developmental conditions are based on $20-\mu l$ spots containing a single strain). The protein concentration attributed to the recipient fone-half the total concentration) was used to calculate the specific activity of $\beta$-galactosidase, because only the recipient carried a lacZ gene. To ensure that equal amounts of the two strains had been mixed, each of the original TPM cell suspensions, prior to mixing, was also spotted in 10- and 20- $\mu$ l aliquots on TPM plates to determine the background levels of $\beta$-galactosidase and the protein concentration contributed by each strain.

The mixtures of recipient $\mathrm{A}^{-} \mathrm{S}^{-}$cells and donor cells were also spotted on CTT plates to detect motility stimulation by light microscopy, using the criteria of Hodgkin and Kaiser (1977, 1979b).

\section{Acknowledgments}

This investigation was supported by grant GM-23441 from the National Institutes of Health (NIH) and is based upon work supported by the National Science Foundation under grant
DCB-8607842. Stipend support was provided by NIH training grant GM-07599 for L.K., by AGO-2908 for K.S. and by an American Cancer Society postdoctoral fellowship for P.H.

\section{References}

Avery, L. and D. Kaiser. 1983. In situ transposon replacement and isolation of a spontaneous tandem genetic duplication. Mol. Gen. Genet. 191: 99-109.

Campos, J.M., J. Geisselsoder, and D.R. Zusman. 1978. Isolation of bacteriophage $\mathrm{Mx}$ 4, a generalized transducing phage for Myxococcus xanthus. J. Mol. Biol. 119: 167-178.

Hagen, D.C., A.P. Bretscher, and D. Kaiser. 1978. Synergism between morphogenetic mutants of Myxococcus xanthus. Dev. Biol. 64: 284-296.

Hodgkin, J., and D. Kaiser. 1977. Cell-to-cell stimulation of movement in nonmotile mutants of Myxococcus. Proc. Natl. Acad. Sci. 74: 2938-2942.

- 1979a. Genetics of gliding motility in Myxococcus xanthus (Myxobacterales): Genes controlling movement of single cells. Mol. Gen. Genet. 171: 167-176.

- 1979b. Genetics of gliding motility in Myxococcus xanthus (Myxobacterales): Two gene systems control movement. Mol. Gen. Genet. 171: 177-191.

Inouye, M., S. Inouye, and D. Zusman. 1979. Biosynthesis and self-assembly of protein $S$, a development specific protein of Myxococcus xanthus. Proc. Natl. Acad. Sci. 76: 209-213.

Kroos, L. and D. Kaiser. 1984. Construction of Tn5 lac, a transposon that fuses $\operatorname{lac} Z$ expression to exogenous promoters, and its introduction into Myxococcus xanthus. Proc. Natl. Acad. Sci. 81: 5816-5820.

. 1987. Expression of many developmentally regulated genes in Myxococcus depends on a sequence of cell interactions. Genes Dev. 1: 840-854.

Kroos, L., A. Kuspa, and D. Kaiser. 1986. A global analysis of developmentally regulated genes in Myxococcus xanthus. Dev. Biol. 117: 252-266.

Kuner, J. and D. Kaiser. 1982. Fruiting body morphogenesis in submerged cultures of Myxococcus xanthus. I. Bacteriol. 151: 458-461.

Kuspa, A., L. Kroos, and D. Kaiser. 1986. Intercellular signalling is required for developmental gene expression in Myxococcus xanthus. Dev. Biol. 117: 267-276.

Reichenbach. H. 1965. Rhythmische vorgange bei der schwarmentfaltung von myxobacterien. Ber. Dtsch. Bot. Ges. 78: $102-105$.

- 1966. Myxococcus spp. (Myxobacterales) schwarmentwicklung und Bildung von protocysten, vol. 1A, pp. 557-578. Publikationen $\mathrm{zu}$ wissenschaftlichen Filmen, Gottingen.

Reichenbach, H. and M. Dworkin. 1981. The order Myxobacterales In The prokaryotes (ed. M.P. Starr, H. Stolp, H.G. Truper, A. Balows and H.G. Schlegel). pp. 328-355. Springer-Verlag, Berlin.

Rosenberg. E. 1984. Myxobacteria. Development and cell interactions. Springer-Verlag, New York.

Shimkets, L.J. and D. Kaiser. 1982a. Induction of coordinated movement of Myxococcus xanthus cells. I. Bacteriol. 152: 451-461.

Shimkets, L., R. Gill, and D. Kaiser. 1983. Developmental cell interactions in Myxococcus xanthus and the spoC locus. Proc. Nat1. Acad. Sci. 80: 1406-1410.

Sodergren, E. and D. Kaiser. 1983. Insertions of Tn5 near genes that govern stimulatable cell motility in Myxococcus. $I$. Mol. Biol. 167: 295-301. 
Stephens, K. and D. Kaiser. 1987. Genetics of gliding motility in Myxococcus xanthus: Molecular cloning of the mgl locus. Mol. Gen. Genet. 207: 256-266.

Teintze, M., R. Thomas, T. Furuichi, M. Inouye, and S. Inouye. 1985. Two homologous genes coding for spore-specific proteins are expressed at different times during development of Myxococcus xanthus. I. Bacteriol. 163: 121-125.

Wireman, J.W. and M. Dworkin. 1975. Morphogenesis and developmental interactions in myxobacteria. Science 189: $516-522$.

Zusman, D.R. 1984. Developmental program of Myxococcus xanthus. 


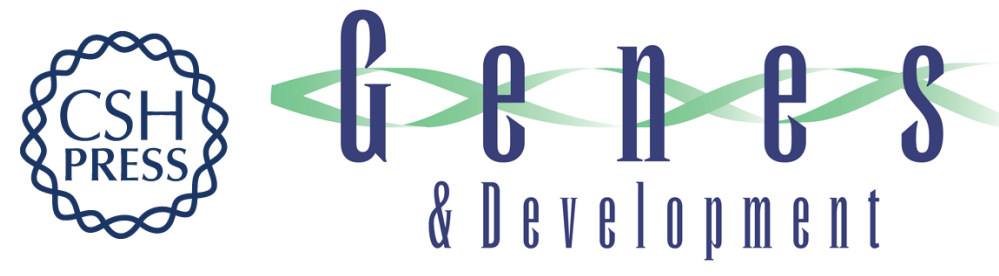

\section{A link between cell movement and gene expression argues that motility is required for cell-cell signaling during fruiting body development.}

L Kroos, P Hartzell, K Stephens, et al.

Genes Dev. 1988, 2:

Access the most recent version at doi:10.1101/gad.2.12a.1677

References This article cites 19 articles, 9 of which can be accessed free at:

http://genesdev.cshlp.org/content/2/12a/1677.full.html\#ref-list-1

License

Email Alerting Service

Receive free email alerts when new articles cite this article - sign up in the box at the top right corner of the article or click here.

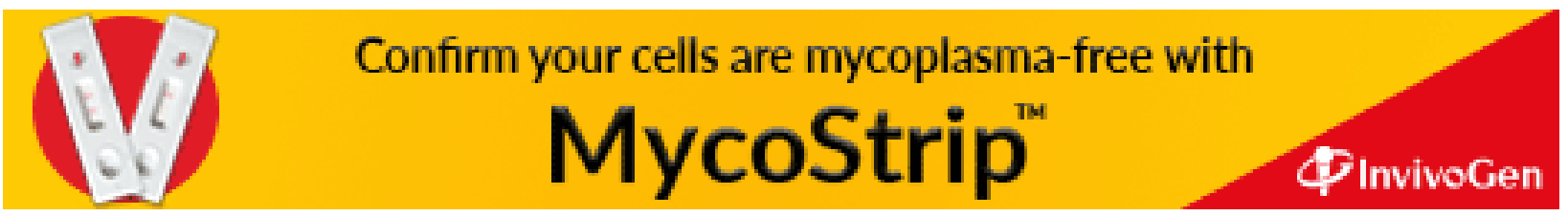

